\title{
Article \\ Genetic variability, correlation and path analysis of exotic and local hybrid maize (Zea mays L.) genotypes
}

\author{
Nlima Ahmed ${ }^{1}$, Abul Kashem Chowdhury ${ }^{1}$, Md. Saleh Uddin ${ }^{2}$ and Md. Mainul Islam Rashad ${ }^{1 *}$ \\ ${ }^{1}$ Department of Genetics and Plant Breeding, Patuakhali Science and Technology University, Dumki, \\ Patuakahali-8602, Bangladesh \\ ${ }^{2}$ Regional Agricultural Research Station, Bangladesh Agricultural Research Institute, Barishal, Bangladesh
}

*Corresponding author: Md. Mainul Islam Rashad, Department of Genetics and Plant Breeding, Faculty of Agriculture, Patuakhali Science and Technology University, Patuakhali-8602, Bangladesh. E-mail: mainul_gpb@pstu.ac.bd

Received: 06 January 2020/Accepted: 18 February 2020/ Published: 31 March 2020

\begin{abstract}
The genetic parameters, characters association and path coefficient analysis between yield and yield components of 32 exotic and local hybrid maize genotypes were studied at Plant Breeding division, Regional Agricultural Research Station (RARS), Bangladesh Agricultural Research Institute (BARI), Rahmatpur, Barisahl during rabi 2015 to 2016, following Alpha Lattice Design with three replications. All the characters showed significant differences among the genotypes except cob length indicating their wide genetic variation. The highest genotypic co-efficient of variation (11.48) observed in yield and lowest (1.72) was found in days to maturity. All of the characters exhibited moderate to high heritability in broad sense $\left(h^{2} b\right)$ coupled with a wide range of genetic advance and genetic advance in percentage of mean. Heritability ranged from 19.21 to 86.79 for cob length and thousand seed weight, respectively. Yield had a significant positive correlation with cob length, cob diameter, number of seeds per cob and number of rows per cob. Days to tasseling and number of seeds per cob make highest positive contribution toward yield. While, days to silking and ear height had highest negative direct effect on yield. The results indicated that ear height, number of rows per cob, thousand seeds weight and number of seeds per cob could be considered as selection criteria in maize breeding program.
\end{abstract}

Keywords: maize; correlation co-efficient; path analysis

\section{Introduction}

Maize is the third most important cereal crop after rice and wheat contributing to agricultural economy of Bangladesh in various ways. Maize is gaining importance in recent years as a promising crop aimed in boosting agricultural growth in Bangladesh. The area and production of maize in 2017-18 was 4.4 lac hectares and 3.3 million tons, respectively (USDA, 2018). In Bangladesh maize is extensively used as poultry feed. The total maize cultivated area in Bangladesh was 3.96 million hectare, production was 27.59 million metric tons and national average yield was 6.97 ton per hectare in 2015-16 (DAE, 2017). The acreage and production of maize in the country is increasing but not encouraging enough compared to the world perspective, and the demand of the crop in the country is increasing at a higher rate. To meet the ever increasing demand of increasing population of Bangladesh maize breeders need to pay special attention to investigate the genetic diversity of maize that could develop genotypes with higher yield and better quality. The availability of adequate genetic diversity is crucial for gaining significant genetic progress in applied breeding programs. Yield of maize like rest crops is the final product attributed by a complex chain of interrelating effects of different characters (Singh et al., 2005). Therefore, Determination of correlation and path coefficients between yield and yield traits is important for the selection of favorable plant types for effective maize breeding programs. Correlation coefficients in general show associations among independent characteristics and the degree of linear relation between these characteristics. It is not sufficient to describe their relationship when the causal association 
among characteristics is needed (Toker and Cagirgan, 2004). Genetic correlation analysis is a handy technique which elaborates the degree of association among important quantitative traits. The studies on correlation are quite old and extensive but, unfortunately, there is hardly any rule set on how much a character contributes towards the expression of other charater(s) in a plant population.

Path analysis is used to determine the amount of direct and indirect effect of the casual component on the effect component. Keeping this in view, the present study was therefore, designed to genetic basis of grain yield components and to develop a suitable selection criterion for future maize breeding program.

Keeping in view many other factors, the genetic base of the material under study and the effects of environment are very important while studying genetic correlation among various quantitative characters in crop species. Such studies could lead plant breeders in the selection of traits contributing towards the character(s) of concern, and ultimately their improvement through hybridization. Accordingly, the present study was carried out with the objective of generating information on variability, and relationship among yield and yield contributing traits to find important traits for selection process.

\section{Materials and Methods}

\subsection{The genotypes, study area and experimental design}

The experiment material for the present investigation comprised of nine local hybrids (IM 8013, IM 8119, BMS02, BMA01, BMA02, BMA03, BHM 6, BHM 7, BHM 9) and 23 exotic (9120, Titan, 987, 942, Elite, Super Gold, PAC 339, PAC 999 Super, PAC 293, 984, NK 40, Sunshine, PS-999, 25K60, Kaveri 50, CP 838, CP808, Pioneer 30V92, Pioneer 30V07, Pioneer 3396, VA Shaktiman, HP-701, BMS01) hybrid maize genotypes were studied following Alpha Lattice Design with three replications at Plant Breeding division, Regional Agricultural Research Station (RARS), Bangladesh Agricultural Research Institute (BARI), Rahmatpur, Barisahl during rabi 2015 to 2016. The unit plot size was $4.0 \times 0.6 \mathrm{~m}$ long. The spacing was adopted $60 \mathrm{~cm}$ between rows and $20 \mathrm{~cm}$ between hills. Two border rows were used at each end of the replication to minimize the border effect.

\subsection{Data collection and statistical analysis}

Five randomly selected plants of each plot were separately harvested for recording yield attributes and other data. The inner two lines were harvested for recording grain yield. The studied characters were Days to tasseling (DT), Days to silking (DS), Days to maturity (DM), Plant height (PH), Ear height (EH), Cob length (CL), Number of rows per cob (NRPC), Number of seeds per cob (NSPC), Thousand grain weight (TGW), Cob Diameter (CD), Yield (Y). Analysis of variance was done for all the characters under study using the mean values (Singh and Chaudhury, 1985). Genotypic and phenotypic variances were estimated according to the formula given by Johnson et al. (1995). Heritability in broad sense (h2b) was estimated according to the formula suggested by Johnson et al. (1955) and Hanson (1961). Genotypic and phenotypic co-efficient of variations were estimated according to Burton (1952) and Singh and Choudhury (1985). Genetic advance was calculated following formula given by Johnson et al. (1955) and Allard (1975). Genetic advance in percent of mean was calculated by the formula of Comstock et al. (1952). The phenotypic correlations were estimated by the formula suggested by Miller et al. (1958). Correlation coefficient were further partitioned into components of direct and indirect effects by path coefficient analysis originally developed by Wright (1921) and later described by Dewey and $\mathrm{Lu}(1959)$.

\section{Results and Discussion}

Analysis of variance (ANOVA) was done to split the total variability into traceable components (Table 1). ANOVA indicate that there was a substantial amount of variability in all of the character but cob length (Table 2). Genotypic and phenotypic co-efficient of variation was low for almost all of the characters studied in the present study. The phenotypic co-efficient of variation (PCV) were higher than their corresponding genotypic co-efficient of variation (GCV) for all the characters studied indicating that they all interacted with the environment to some intent. Phenotypic co-efficient of variation ranged from 2.27 to 13.25 for days to maturity and yield respectively. While the highest genotypic coefficient of variation (11.48) observed in yield and lowest (1.72) was found in days to maturity (Table 3). All of the characters exhibited moderate to high heritability in broad sense $\left(h^{2} b\right)$ coupled with a wide range of genetic advance and genetic advance in percentage of mean. Heritability ranged from 19.21 to 86.79 for cob length and thousand seed weight respectively.

Number of seeds per cob and yield showed genetic advance and genetic advance in percentage of mean, which indicated the possibility of additive genes effect for the expression of this character. Therefore, selection would be effective for producing varieties with reduced plant from the genotypes under study. On the other hand, ear 
height, number of rows per cob and thousand seeds weight showed moderate genetic advance and genetic advance in percentage of mean indicating high degree of genetic variability for this character. Therefore, there is a good scope of isolating good genotypes based on this trait. Days to maturity, cob length, days to tasseling, days to sinking, cob diameter and plant height low genetic advance and genetic advance in percentage of mean indicating the actions of both additive and non-additive genes in the expression of this trait i.e. the scope of improvement of this character by direct selection would be also limited.

Several researches (El- Hefnawy and El- Zeir, 1991; Nawar et al., 1991; Mohamed, 1993) studied the genetic variance and heritability in corn, concerning narrow sense heritability, it was found to be high for ear height, ear diameter, 100- kernel weight and grain yield (Robinson et al., 1949; EL- Agamy et al., 1992; Mourad et al., 1992; Robinson et al., 1949) found that additive genetic variance had more important role in the expression for plant and ear height. Amer and Mosa (2004) reported that heritability estimates in narrow sense were $44 \%$ for silking date, $39 \%$ for plant height, $44 \%$ for ear height, $27 \%$ for ear length, $31 \%$ for ear diameter, $29 \%$ for number of rows per ear, 23\% for number of kernels per row and 36\% for grain yield. Yassien (1993) found that the narrow sense heritability estimates were $65 \%$ for plant height, $51 \%$ for ear length, $63 \%$ for ear diameter, 44 $\%$ for number of rows per ear, $66 \%$ for number of kernels per row, $42 \%$ for 100 -kernel weight and $27 \%$ for grain yield. Table 4 and Table 5 represent the genotypic and phenotypic correlation coefficient. Days to tasseling found to display significant positive relationships with day to silking and ear height. It also showed significant negative relationship with cob diameter, number of rows per cob, yield and number of seeds per cob. Days to to silking was found highly significant positive relationships with days to ear height and days to tasseling. Cob diameter, number of rows per cob and thousand grain weight showed significant negative correlation with days to silking. Days to maturity was found highly significant positive relationships with number of rows per cob and number of seeds per cob. Days to maturity showed significant negative correlation with ear height. Plant height showed significant positive relationship with ear height. Days to maturity were found significant negative correlation with ear height. Ear height showed significant positive relationships with days to tasseling, days to silking and plant height.

Cob length showed significant positive relationships with number of rows per cob, number of seeds per cob and yield. Cob Diameter were found significant negative relationships with days to tasseling and days to sidling. This trait showed significant positive relationships with number of rows per cob, number of seeds per cob and yield. Number of rows per cob was found highly significant positive relationships with days to maturity, cob length, cob diameter, number of seeds per cob and yield. This trait also showed significant negative relationship with days to tasseling and days to silking. Number of seeds per cob was found highly significant positive relationships with days to maturity, cob length, cob diameter, number of rows per cob and yield. This trait also showed significant negative relationship with days to tasseling. Thousand grain weight did not show any significant positive relationships with other characters. Thousand grain weight was found significant negative correlation with days to silking. Fruit weight was found highly significant positive relationships with fruit cob length, cob diameter, number of rows per cob and number of seeds per cob and significant negative relationship with days to tasseling.

Many investigators determined the associations among different characters in corn. Moursi et al. (1975) mentioned that number of kernels per row, ear diameter and 100-kernel weight had consistent positive and significant correlations with grain yield. Katta (1976) found positive and significant correlation between grain yield and each of plant height, number of rows per ear, number of kernel per row and 100- kernel weight and emphasized the role of these traits in selection of high grain yield in corn. Also, (AL- Ahmad, 2004; Aydin et al., 2007; Najeeb et al., 2009) indicated that the correlation values were positive and significant between grain yield and each of ear diameter, ear length and number of kernels per row. El-Shouny et al. (2005) and Tollenaar et al. (2004) identified different traits like ear length, ear diameter, kernels per row, ears per plant, 100-seed weight and rows per ear as potential selection criteria in breeding programs aiming at higher yield. Grain yield is positively genetically correlated with days to silking and tasselling (Altenbas and Algan, 1993; Ahmad, 1997; Rather et al., 1999). Some other published results are contrary to this (Umakanth et al., 2000). Plant and ear heights are strongly associated with grain yield (Martin and Russell, 1984; Burak and Magoja, 1991; Singh and Dash, 2000; Umakanth et al., 2000), but Rather et al. (1999) reported the association of plant height with grain yield as non-significant. Similarly, strong genetic correlation exists between grain yield and leaf area (Khakim et al., 1998; Lee et al., 2001). Number of ears per plant and ear weight are also strongly associated with grain yield (Martin and Russell, 1984; Khakim et al., 1998). Ear height, ear length and ear diameter have also positive genetic correlation with grain yield (Burak and Magoja, 1991; Malvarr et al., 1994; Khatun et al., 1999; Singha and Prodhan, 2000) but negatively with kernel weight (Martin and Russell, 1984). Number of kernels row ${ }^{-1}$ and kernel rows ear ${ }^{-1}$ also have positive genetic correlation with grain yield (Shalygina, 1990; Altenbas and Algan, 


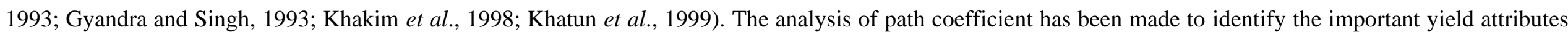

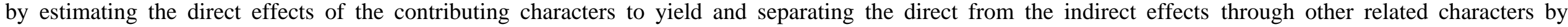

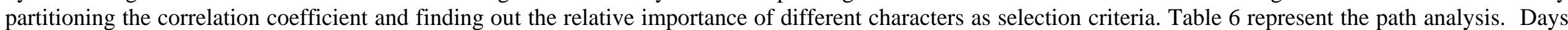

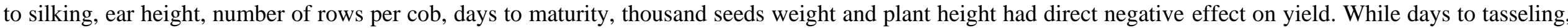

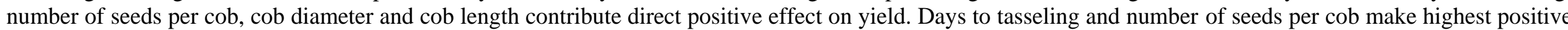

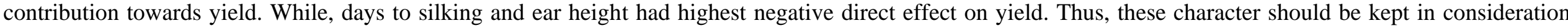

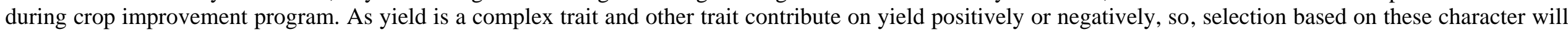

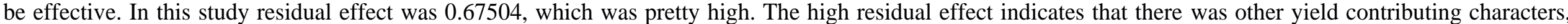

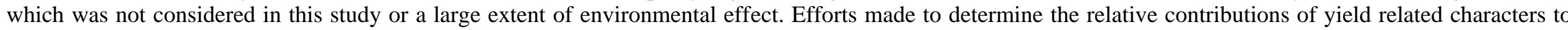

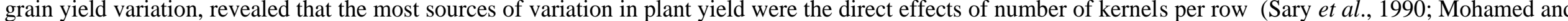

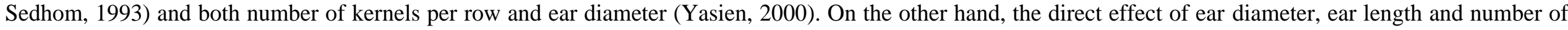

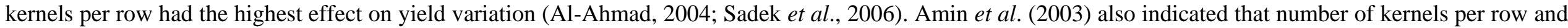
100 -kernel weight were the highest contributors to variation in grain yield directly or indirectly.

Table 1. Maximum, minimum, mean, standard deviation and variance for different characters of thirty-two maize genotypes.

\begin{tabular}{|c|c|c|c|c|c|c|c|c|c|c|c|}
\hline Characters & $\begin{array}{l}\text { Days to } \\
\text { tasseling }\end{array}$ & $\begin{array}{l}\text { Days to } \\
\text { silking }\end{array}$ & $\begin{array}{ll}\text { Days } & \text { to } \\
\text { maturity } & \end{array}$ & $\begin{array}{l}\text { Plant } \\
\text { Height }\end{array}$ & $\begin{array}{l}\text { Ear } \\
\text { height }\end{array}$ & $\begin{array}{l}\text { Cob } \\
\text { length }\end{array}$ & $\begin{array}{l}\text { Cob } \\
\text { Diameter }\end{array}$ & $\begin{array}{l}\text { Number of } \\
\text { rows per } \\
\text { cob }\end{array}$ & $\begin{array}{l}\text { Number of } \\
\text { seeds per cob }\end{array}$ & $\begin{array}{l}1000 \text { grain } \\
\text { weight }\end{array}$ & Yield \\
\hline Max & 90.00 & 93.00 & 156.00 & 300.66 & 157.00 & 21.60 & 5.50 & 18.00 & 748.00 & 549.30 & 9.25 \\
\hline Min & 79.00 & 82.00 & 142.00 & 232.66 & 89.33 & 15.00 & 4.40 & 12.00 & 458.00 & 352.60 & 5.01 \\
\hline Mean & 82.36 & 85.56 & 149.02 & 271.78 & 126.88 & 18.27 & 5.02 & 15.23 & 600.01 & 418.22 & 6.92 \\
\hline Standard deviation & 2.471 & 2.536 & 3.360 & 13.195 & 12.083 & 1.311 & 0.228 & 1.407 & 63.029 & 34.340 & 0.912 \\
\hline Variance & 6.107 & 6.434 & 11.291 & 174.115 & 146.005 & 1.717 & 0.052 & 1.979 & 3972.698 & 1179.237 & 0.831 \\
\hline
\end{tabular}

Table 2. Analysis of variance (mean squares) for different characters of 32 genotypes of maize.

\begin{tabular}{|c|c|c|c|c|c|c|c|c|c|c|c|c|}
\hline \multirow{2}{*}{$\begin{array}{l}\text { Source of } \\
\text { Variation }\end{array}$} & \multirow{2}{*}{$\begin{array}{l}\text { Degree of } \\
\text { freedom }\end{array}$} & \multirow{2}{*}{$\begin{array}{l}\text { Days to } \\
\text { tasseling }\end{array}$} & \multicolumn{10}{|c|}{ Mean squares value of } \\
\hline & & & $\begin{array}{ll}\text { Days } & \text { to } \\
\text { silking } & \end{array}$ & $\begin{array}{l}\text { Days to } \\
\text { maturity }\end{array}$ & $\begin{array}{l}\text { Plant } \\
\text { Height }\end{array}$ & $\begin{array}{l}\text { Ear } \\
\text { height }\end{array}$ & $\begin{array}{l}\text { Cob } \\
\text { length }\end{array}$ & $\begin{array}{l}\text { Cob } \\
\text { diameter }\end{array}$ & $\begin{array}{l}\text { Number } \\
\text { of rows } \\
\text { per cob }\end{array}$ & $\begin{array}{l}\text { Number of } \\
\text { seeds per } \\
\text { cob }\end{array}$ & $\begin{array}{l}1000 \text { grain } \\
\text { weight }\end{array}$ & Yield \\
\hline Replication & 2 & 0.948 & 0.094 & 11.167 & 85.31 & 87.069 & 0.376 & 0.002 & 0.015 & 685.073 & 366.998 & 0.727 \\
\hline Factor A & 31 & $14.975^{* *}$ & $16.655^{* *}$ & 24.579 & $436.927 * *$ & $339.364 * *$ & $2.443^{\mathrm{ns}}$ & $0.115^{* *}$ & $4.762 * *$ & $11166.4^{*}$ & $3308.705 * *$ & $2.109 * *$ \\
\hline Error & 62 & 1.937 & 1.631 & 4.833 & 48.382 & 53.582 & 1.426 & 0.023 & 0.682 & 545.976 & 159.724 & 0.211 \\
\hline
\end{tabular}


Table 3. Heritability, genetic advance and genetic advance in percentage of mean in respect of yield and yield contributing characters of Maize.

\begin{tabular}{|c|c|c|c|c|c|c|c|c|}
\hline Characters & $\sigma_{g}^{2}$ & $\sigma_{e}^{2}$ & $\sigma_{p}^{2}$ & PCV & GCV & $\mathrm{h}_{\mathrm{b}}^{2}(\%)$ & GA & $\% \mathrm{GA}$ \\
\hline DT & 4.35 & 1.94 & 6.28 & 3.04 & 2.53 & 69.17 & 3.57 & 4.34 \\
\hline DS & 5.01 & 1.63 & 6.64 & 3.01 & 2.62 & 75.43 & 4.00 & 4.68 \\
\hline DM & 6.58 & 4.83 & 11.42 & 2.27 & 1.72 & 57.66 & 4.01 & 2.69 \\
\hline PH & 129.52 & 48.38 & 177.90 & 4.91 & 4.19 & 72.80 & 20.00 & 7.36 \\
\hline EH & 95.26 & 53.58 & 148.84 & 9.62 & 7.69 & 64.00 & 16.08 & 12.68 \\
\hline CL & 0.34 & 1.43 & 1.76 & 7.27 & 3.19 & 19.21 & 0.53 & 2.88 \\
\hline CD & 0.03 & 0.02 & 0.05 & 4.62 & 3.47 & 56.66 & 0.27 & 5.39 \\
\hline NRPC & 1.36 & 0.68 & 2.04 & 9.39 & 7.66 & 66.59 & 1.96 & 12.87 \\
\hline NSPC & 3540.14 & 545.98 & 4086.12 & 10.65 & 9.92 & 86.64 & 114.09 & 19.01 \\
\hline TGW & 1049.66 & 159.72 & 1209.38 & 8.32 & 7.75 & 86.79 & 62.18 & 14.87 \\
\hline YLD & 0.63 & 0.21 & 0.84 & 13.25 & 11.48 & 74.99 & 1.42 & 20.48 \\
\hline
\end{tabular}

$\sigma_{\mathrm{g}}^{2}=$ Genotypic variation, $\sigma_{\mathrm{e}}^{2}=$ Environmental variation, $\sigma_{\mathrm{p}}^{2}=$ Phenotypic variation,

$\mathrm{GCV}=$ Genotypic co-efficient of variance, $\mathrm{PCV}=$ Phenotypic co-efficient of variance, $\mathrm{GA}=$ Genetic advance, $\% \mathrm{GA}=$ genetic advance in percentage of mean

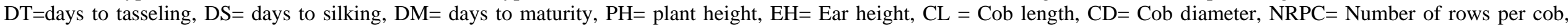
$\mathrm{NSPC}=$ Number of seeds per cob, TGW= thousand grain weight, YLD= Yield

Table 4. Genotypic correlations between eleven characters of 32 genotypes of maize.

\begin{tabular}{|c|c|c|c|c|c|c|c|c|c|c|}
\hline & $\begin{array}{l}\text { Days to } \\
\text { silking }\end{array}$ & $\begin{array}{l}\text { Days to } \\
\text { maturity }\end{array}$ & Plant height & Ear height & $\begin{array}{l}\text { Cob } \\
\text { length }\end{array}$ & $\begin{array}{l}\text { Cob } \\
\text { diameter }\end{array}$ & $\begin{array}{l}\text { No. of rows } \\
\text { per cob }\end{array}$ & $\begin{array}{l}\text { No. of seeds } \\
\text { per cob }\end{array}$ & $\begin{array}{l}1000 \text { grain } \\
\text { weight }\end{array}$ & Yield \\
\hline Days to tasseling & $0.989 * *$ & -0.006 & 0.132 & $0.461 * *$ & 0.185 & $-0.567 * *$ & $-0.509 * *$ & $-0.306^{*}$ & -0.261 & $-0.368 * *$ \\
\hline Days to silking & & 0.022 & 0.082 & $0.318^{*}$ & 0.287 & $-0.511 * *$ & $-0.436 * *$ & 0.205 & $-0.304 *$ & -0.228 \\
\hline Days to maturity & & & -0.081 & $-0.559 * *$ & 0.077 & 0.276 & $0.328^{*}$ & $0.325^{*}$ & 0.136 & 0.143 \\
\hline Plant height & & & & $0.460 * *$ & 0.136 & 0.089 & 0.255 & 0.123 & -0.254 & -0.205 \\
\hline Ear height & & & & & 0.211 & -0.187 & 0.164 & -0.105 & -0.230 & -0.196 \\
\hline Cob length & & & & & & 0.260 & $0.544 * *$ & $0.837 * *$ & -0.113 & $0.388 * *$ \\
\hline Cob diameter & & & & & & & $0.862 * *$ & $0.809 * *$ & 0.199 & $0.508 * *$ \\
\hline No. of rows per cob & & & & & & & & $0.966 * *$ & -0.212 & $0.551 * *$ \\
\hline No. of seeds per cob & & & & & & & & & -0.167 & $0.546 * *$ \\
\hline 1000 grain weight & & & & & & & & & & 0.060 \\
\hline
\end{tabular}

$* *, *$ denotes significant at $1 \%$ level of significance, significant at $5 \%$ level of significance respectively. 
Table 5. Phenotypic correlations between eleven characters of 32 genotypes of maize.

\begin{tabular}{|c|c|c|c|c|c|c|c|c|c|c|}
\hline & $\begin{array}{l}\text { Days to } \\
\text { silking }\end{array}$ & \begin{tabular}{|l|} 
Days to \\
maturity
\end{tabular} & Plant height & Ear height & \begin{tabular}{|l|} 
Cob \\
length
\end{tabular} & \begin{tabular}{|l|} 
Cob \\
diameter
\end{tabular} & $\begin{array}{l}\text { No. of rows } \\
\text { per cob }\end{array}$ & $\begin{array}{l}\text { No. of seeds } \\
\text { per cob }\end{array}$ & $\begin{array}{l}1000 \text { grain } \\
\text { weight }\end{array}$ & Yield \\
\hline Days to tasseling & $0.927 * *$ & -0.008 & 0.056 & 0.268 & 0.033 & $-0.412 * *$ & $-0.363 * *$ & -0.223 & -0.182 & -0.295 \\
\hline Days to silking & & 0.005 & 0.021 & 0.207 & 0.124 & $-0.395 * *$ & $-0.310 *$ & -0.144 & -0.229 & -0.200 \\
\hline Days to maturity & & & -0.026 & $-0.365 * *$ & \begin{tabular}{|l|}
-0.024 \\
\end{tabular} & $0.306^{*}$ & 0.257 & 0.258 & 0.127 & 0.192 \\
\hline Plant height & & & & $0.356 * *$ & 0.060 & 0.029 & 0.108 & 0.120 & -0.194 & -0.106 \\
\hline Ear height & & & & & -0.043 & -0.112 & -0.109 & -0.082 & -0.201 & -0.168 \\
\hline Cob length & & & & & & 0.118 & 0.202 & $0.438 * *$ & -0.040 & 0.090 \\
\hline Cob diameter & & & & & & & $0.726 * *$ & $0.635^{* *}$ & 0.166 & 0.395 \\
\hline No. of rows per cob & & & & & & & & $0.826^{* *}$ & -0.161 & $0.416^{* *}$ \\
\hline No. of seeds per cob & & & & & & & & & -0.150 & $0.451 * *$ \\
\hline 1000 grain weight & & & & & & & & & & $0.090 * *$ \\
\hline
\end{tabular}

$* *, *$ denotes significant at $1 \%$ level of significance, significant at $5 \%$ level of significance respectively.

Table 6. Partitioning of genotypic correlations into direct and indirect effects of the studied characters as influenced by thirty-two genotypes by path analysis.

\begin{tabular}{|c|c|c|c|c|c|c|c|c|c|c|c|}
\hline & $\begin{array}{l}\text { Days to } \\
\text { tasseling }\end{array}$ & $\begin{array}{ll}\text { Days } & \text { to } \\
\text { silking } & \end{array}$ & $\begin{array}{l}\text { Days to } \\
\text { maturity }\end{array}$ & $\begin{array}{l}\text { Plant } \\
\text { height }\end{array}$ & Ear height & Cob length & $\begin{array}{l}\text { Cob } \\
\text { diameter }\end{array}$ & $\begin{array}{l}\text { No. of rows } \\
\text { per cob }\end{array}$ & $\begin{array}{l}\text { No. of seeds } \\
\text { per cob }\end{array}$ & $\begin{array}{l}1000 \text { seed } \\
\text { weight }\end{array}$ & Yield \\
\hline $\begin{array}{ll}\text { Days } \\
\text { tasseling }\end{array} \quad$ to & 1.947 & -1.876 & 0.002 & -0.010 & -0.305 & 0.020 & -0.180 & 0.327 & -0.329 & 0.035 & -0.368 \\
\hline $\begin{array}{ll}\begin{array}{l}\text { Days } \\
\text { silking }\end{array} & \text { to } \\
\end{array}$ & 1.925 & -1.897 & -0.009 & -0.006 & -0.211 & 0.031 & -0.162 & 0.280 & -0.220 & 0.041 & -0.228 \\
\hline $\begin{array}{ll}\begin{array}{l}\text { Days } \\
\text { maturity }\end{array} & \text { to } \\
\end{array}$ & -0.012 & -0.042 & -0.396 & 0.006 & 0.370 & 0.008 & 0.088 & -0.210 & 0.349 & -0.018 & 0.143 \\
\hline Plant height & 0.256 & -0.155 & 0.032 & -0.079 & -0.304 & 0.015 & 0.028 & -0.164 & 0.132 & 0.034 & -0.205 \\
\hline Ear height & 0.897 & -0.604 & 0.222 & -0.036 & -0.661 & 0.023 & -0.059 & 0.105 & -0.113 & 0.031 & -0.196 \\
\hline Cob length & 0.360 & -0.545 & -0.031 & -0.011 & -0.140 & 0.107 & 0.082 & -0.349 & 0.900 & 0.015 & 0.388 \\
\hline Cob diameter & -1.103 & 0.970 & -0.110 & -0.007 & 0.124 & 0.028 & 0.317 & -0.554 & 0.869 & -0.027 & 0.508 \\
\hline $\begin{array}{l}\text { No. of rows } \\
\text { per cob }\end{array}$ & -0.992 & 0.828 & -0.130 & -0.020 & 0.108 & 0.058 & 0.273 & -0.642 & 1.038 & 0.028 & 0.551 \\
\hline $\begin{array}{l}\text { No. of seeds } \\
\text { per cob }\end{array}$ & -0.595 & 0.388 & -0.129 & -0.010 & 0.069 & 0.090 & 0.256 & -0.620 & 1.075 & 0.022 & 0.546 \\
\hline $\begin{array}{ll}1000 & \text { grain } \\
\text { weight }\end{array}$ & -0.508 & 0.577 & -0.054 & 0.020 & 0.152 & -0.012 & 0.063 & 0.136 & -0.179 & -0.134 & 0.060 \\
\hline
\end{tabular}

The bold figures indicate direct effect towards yield.

Residual effect $=0.67504$ 


\section{Conclusions}

From the results, it could be concluded that high heritability values in broad sense were accompanied with either higher or moderate genetic advance upon selection particularly for ear height, number of rows per cob, thousand seeds weight, number of seeds per cob and yield. Such results indicated the effectiveness of selection processes in subsequent generations for these traits. For cob length where low heritability values in broad sense were associated with low genetic advance selection may be less effective.

\section{Conflict of interest}

None to declare.

\section{References}

Ahmad S, 1997. Response to selection for grain yield and its components in a maize population. MSc Thesis, Department of Plant Breeding and Genetics, University of Agriculture Faisalabad.

AL-Ahmad AS, 2004. Genetic parameters for yield and its components in some new yellow maize crosses. $\mathrm{PhD}$ Thesis, Faculty of Agriculture, Ain Shams University, Egypt.

Allard RW, 1960. Principles of Plant Breeding, John Wiley and Sons. Inc., New York.

Altbens M and N Algan, 1993. Correlation among earliness, yield, yield components and quality traits in hybrid maize. Anadolu., 3: 40-62.

Amer EA and HE Mosa, 2004. Gene effects of some plant and yield traits in four maize crosses. Minofiya J. Agric. Res., 1: 181-192.

Amin AZ, HA Khalil and RK Hassan, 2003. Correlation studies and relative importance of some plant characters and grain yield in maize single crosses. Arab Univ. J. Agric. Sci., Ain Shams Univ., Cairo, 11: 181-190.

Aydin N, S Gokmen, A Yildirim, A Oz, G Figliuolo and H Budak, 2007. Estimating genetic variation among dent corn inbred lines and top crosses using multivariate analysis. J. Appl. Biol. Sci., 1: 63-70.

Burak R and JL Magoja, 1991. Yield and yield components of full-sib and half-sib families derived from a perennial teosinte introgression population. Maize Genet. Corp newsletter, pp. 67-76.

Burton GM, 1952. Quantitative inheritance in Grass pea. Proc. of $6^{\text {th }}$ Int. Grassland Cong., 1: 277-283.

Comstock RE and HF Robinson, 1952. Genetic parameters their estimation and significance. Proc. of $6^{\text {th }}$ Int. Grassland Cong., 1: 128-291.

DAE, 2017. Krishi Diary. Agricultural Information Service.

Dewey DR and KH Lu, 1959. A correlation and path co-efficient analysis of components of crested wheat seed production. Agron. J., 51: 515-518.

El-Agamy AL, SB Mourad and SE Sadek, 1992. Improvement of grain yield and other characters in two maize pools by S1 progeny selected method. Egypt. J. Appl. Sci., 7: 300-308.

El-Hefnawy NN and FA EI- Zeir, 1991. Studies on the genetic behavior of some parental lines of maize and their single crosses under different environmental factors. Annals of Agric. Sci., 29: 97-116.

El-Shouny KA, OH El-Baguory, KIM Ibrahim and SA Al-Ahmad, 2005. Correlation and path coefficient analysis in four yellow maize crosses under two planting dates. Arab Univ. J. Sci., 13: 327-339.

Gyanendra S and M Singh, 1993. Correlation and path analysis in maize under mid-hills of Sikkim. Crop Improv., 20: 222-5.

Hanson WD, 1963. Heritability. In: WD Hanson and HF Robinson (Eds.). Statistical Genetics and Plant Breeding. NAS-NRC Publication 982. pp. 125-140.

Johnson KF, HF Robinson and RE Comstock, 1955. Genotypic and phenotypic correlation in soybeans and their implication in selection. Agron. J., 47: 477-483.

Katta YS, 1976. A correlation and path coefficient analysis of grain yield components of maize (Zea mays L.). J. Agric. Res. Tanta Univ., 2: 98-114.

Khakim A, S Stoyanova and S Tsankova, 1998. Establishing the correlation between yield and some morphological, reproductive and biochemical characteristics in maize. Rasteniev" dni Nauki, 35: 419-422

Khatun F, S Begum, A Motin, S Yasmin and MR Islam, 1999. Correlation coefficient and path analysis of some maize (Z. mays L.) hybrids. Bangladesh J. Bot., 28: 9-15.

Lee H, SF Jauh, TW Long and LH Shung, 2001. Studies on the agronomic traits and forage yield of three-way cross forage maize hybrids. J. Agric. Res., China, 50: 25-32.

Malvar RA, P Revilla and A Ordas, 1994. Additive correlation between days to flowering and agronomic traits in low land races of maize. Annales de la Estacition Experimental de Aula Dei. 20: 59-64.

Martin MJ and AW Russel, 1984. Correlation response of yield and other agronomic traits to recurrent selection for stalk quality in maize synthetics. Crop Sci., 24: 746-50. 
Miller PA, JC Williams, HF Robinson and RE Comstock, 1958. Estimation of genetic and environmental variance and covariance and their implication in selection. Agron. J., 50: 126-131.

Mohammed MK, 1993. Estimation of variability and covariability in maize (Zea mays L.) under different levels of nitrogen fertilization. Annals of Agric. Sci. Ain Shams, Univ., Cairo, 38: 551-564.

Mohammed MK and SA Sedhom, 1993. A comparison between four statistical procedures of relating yield components in set of corn varieties. Annals of Agric. Sci., 31: 1855-1866.

Mourad SB, SE Sadek, AL El- Agamy and HS Soliman, 1992. Genetic variance in two maize pools estimated by reciprocal half- sib selection method. Egypt. J. Appl. Sci., 7: 585-597.

Moursi MA, FT Oraby, EM Zeidan and SA Nigem, 1975. The contribution effect of some yield components to the grain yield of maize (Zea mays L.). Zagazig J. Agric. Res., 2: 143-153.

Najeeb S, AG Rather, GA Parray, FA Sheikh and SM Razvi, 2009. Studies on genetic variability, genotypic correlation and path coefficient analysis in maize under high altitude temperate ecology of Kashmir. Maize Genetics Cooperation Newsletter, 83: 1-8.

Nawar Aa, HA Dawwam, ME Ibrahim and ANM Khalil, 1991. Effect of plant densities on phenotypic and genotypic estimates in maize. J. Agric. Res. Tanta Univ. 17: 187-199.

Rather AG, FA Sheikh and SA Wani, 1999. Variability and correlation studies in maize (Zea mays L.) under rainfed conditions. Adv. Plant Sci., 12: 539-42

Robinson HF, RE Comstock and PH Harvey, 1949. Estimates of heritability and the degree of dominance in corn. Agron. J., 41: 353-359.

Sadek SE, MA Ahmed and AHM El-Ghaney, 2006. Correlation and Path coefficient analysis in five parents inbred lines and their six white maize (Zea mays L.) single crosses developed and grown in Egypt. J. App. Sci. Res., 2: 159-167.

Sary GA, AA El Hosary, SA Mohamed and AAA El-Sattar, 1990. Studies on combining ability and heterosis in maize (Zea mays, L.) III- Association studies. Egypt. J. Agron., 15: 1-8.

Shalygina OM, 1990. Correlation of yield in maize plants with its yield components and biological characters under irrigation in the lower Volga area. Genetike-i-Selektsii, 134: 10-14.

Singh P, V Sain, VK Dwivedi, Y Kumar and O Sangwan, 2005. Genetic divergence studies in maize (Zea mays L.). Annals of Agricultural and Biological Research, 10: 43-46.

Singh JM and B Dash, 2000. Analysis of genetic variability and character association in maize. African Crop Sci. J., 5:1-8

Singh RK and BD Chaudhury, 1985. Biometrical Methods in Quantitative Genetic Analysis (rev. edition). Kalyani Publisher, New Delhi, India.

Singh N and SH Pradhan, 2000. Character association in green maize. Env. Eco., 18: 962-965.

Toker C and MI Cagirgan, 2004. The use of phenotypic correlations and factor analysis in determining characters for grain yield selection in chickpea (Cicer arietinum L.). Hereditas, 140: 226-228.

Tollenaar M, A Ahmadzadeh and EA Lee, 2004. Physiological basis of heterosis for grain yield in maize. Crop Sci., 44: 2086-2094.

Umakanth AV, E Satyanarayana and MV Kumar, 2000. Correlation and heritability studies in Ashwini maize composite. Ann. Agric. Res. 21: 228-230.

Yasien M, 2000. Genetic behavior and relative importance of some yield components in relation to grain yield in maize (Zea mays L.). Annals of Agric. Sci., 38: 689-700.

Yassien HE, 1993. Genetic analysis in three yellow maize (Zea mays L.) crosses. J. Agric. Mansoura, Univ., 24: 5319-5331.

USDA, 2018. Foreign Agricultural Service, Grain and Feed Annual, Dhaka, Bangladesh.

Wright S, 1921. Correlation and causation. J. Agric. Res., 20: 557- 585. 